\title{
An RNA symbiont enhances heat tolerance and secondary homothallism in the oomycete Phytophthora infestans
}

Correspondence

Howard S. Judelson

Howard.Judelson@ucr.edu

Received 2 March 2010

Accepted 25 March 2010

\author{
Howard S. Judelson, Audrey M. V. Ah-Fong and Anna-Liisa Fabritius \\ Department of Plant Pathology and Microbiology, University of California, Riverside, CA 92521 , \\ USA
}

\begin{abstract}
Some strains of Phytophthora infestans, the potato late blight pathogen, harbour a small extrachromosomal RNA called PiERE1. A previous study reported that this RNA symbiont does not noticeably affect its host. Here it is revealed that PiERE1 exerts subtle effects on $P$. infestans, which result in greater thermotolerance during growth and an increase in secondary homothallism, i.e. oospore formation in the absence of the opposite mating type. The interaction can be considered mutualistic since these traits may increase the fitness of $P$. infestans in nature. Assays of biomarkers for cellular stress revealed that an $\mathrm{Hsp} 70$ chaperone was upregulated by PiERE1. A genome-wide search for more members of the Hsp70 family identified ten belonging to the DnaK subfamily, one in the Hsp110/SSE subfamily, and pseudogenes. Four DnaK subfamily genes encoding predicted cytoplasmic or endoplasmic reticulum proteins were upregulated in strains harbouring PiERE1. This may explain the greater thermotolerance conferred by the RNA element, and suggests that Hsp70 may be a useful biomarker for testing organisms for the cellular effects of symbiotic elements.
\end{abstract}

\section{INTRODUCTION}

Many parasites do not always elicit obvious symptoms in their hosts and are described as causing cryptic (asymptomatic) or latent infections (Roossinck, 2008). Whether such overtly benign interactions actually have cellular consequences is poorly understood. Many eukaryotic microbes such as fungi and oomycetes contain virus-like particles that do not obviously affect their hosts, for example, and some plant viroids and bacterial phages cause disease in only a subset of hosts or growth conditions (Flores et al., 2005; Oppenheim et al., 2005; Pearson et al., 2009). Such agents may have caused strong symptoms at some point, but evolutionary pressures probably diminished their effects and in some cases caused shifts to mutualisms. Examples of the latter include the killer systems of Kluyveromyces lactis and other yeasts that reduce competition for environmental resources, and a virus of the endophytic fungus Curvularia protuberata that helps it grow in plants at elevated temperatures (Márquez et al., 2007; Schmitt \& Breinig, 2006). Mutualistic infections by virus-like agents are also described in animals, such as in the pea aphid, where a phage of its endosymbiotic bacterium expresses a toxin that protects the aphid from parasites; in wasps parasitic on lepidopterans, in which ascoviruses suppress defences against the wasp, and in many species where viruses prevent superinfection or boost

Abbreviation: ER, endoplasmic reticulum. the immune system (Deterding et al., 2006; Moran et al., 2005; Stasiak et al., 2005; van Nunen et al., 2001).

Investigations of virus-like agents of plant pathogens spiked following the discovery of a mycovirus that inhibits the chestnut blight fungus (Van Alfen et al., 1975), but most entities that have been discovered cause only cryptic infections. In oomycetes, for example, some strains of Phytophthora and Pythium species were found to contain virus-like particles or double-stranded RNA that appear to not harm their hosts (Cai et al., 2009; Hacker et al., 2005; Klassen et al., 1991; Newhouse et al., 1992).

We described previously an enigmatic RNA symbiont from Phytophthora infestans, the potato late blight pathogen (Judelson \& Fabritius, 2000). The RNA, named here as PiERE1 ( $P$. infestans extrachromosomal RNA element), comprises a $625 \mathrm{nt}$ linear single-stranded molecule that lacks an obvious open reading frame or sequence similarity to any known agent, does not copurify with other RNAs, and appears to be unencapsidated. It is predicted to fold into a largely double-stranded structure that may form a pseudocircle by annealing its $3^{\prime}$ polyadenine tail with a $5^{\prime}$ terminal uracil tract. PiERE1 replicates to a level of about $1 \%$ of total mRNA through an unknown mechanism. Strains with the parasite lack complementary DNA, indicating that it is not transcribed from a chromosomal or extrachromosomal DNA template. Most PiERE1 copurifies with nuclei, with little if any found in mitochondria, while showing a partial bias towards maternal inheritance in 
sexual crosses. Very few natural isolates contain PiERE1, which is perhaps best described as an RNA plasmid.

Our prior study reported that PiERE1 did not noticeably alter the growth, sporulation, germination or pathogenic fitness of $P$. infestans (Judelson \& Fabritius, 2000). We now show, however, that PiERE1 exerts subtle effects on its host that aid growth at elevated temperatures, enhance secondary homothallism, and may promote the survival of $P$. infestans in nature. These traits could be a consequence of cellular stress instigated by PiERE1, since the symbiont elevates the expression of several genes encoding the Hsp70 protein chaperone, which is a typical biomarker of stress.

\section{METHODS}

Strains and culture conditions. Strains 510 (A2 mating type), 3117 (A1 mating type), and their progeny were as described previously (Judelson \& Fabritius, 2000). Other strains were 88069 (A1, from The Netherlands), 1306 (A1, USA), and 618 (A2, Mexico). Cultures were maintained in the dark at $18{ }^{\circ} \mathrm{C}$ on rye-sucrose medium (Caten \& Jinks, 1968) containing $1.5 \%$ agar in $60 \mathrm{~mm}$ plates sealed with plastic film. Growth assays involved inoculating $150 \mathrm{~mm}$ plates with $5 \times 5 \mathrm{~mm}$ plugs of mycelium, which were incubated for 2 days at $18{ }^{\circ} \mathrm{C}$ to establish consistent growth and then shifted to the desired temperature. Colony edges were marked daily and growth scored between days 3 and 6 . Tests for secondary homothallism involved excising $5 \times 5 \mathrm{~mm}$ plugs from cultures after 1.5 months, which were squashed under a cover glass and checked for oospores; counts were averaged from four locations per culture, and biological replicates were performed at 3-4-week intervals.

Growth measurements in tomato. Infections were established by dipping detached tomato leaflets (cv. Sun Gold) in suspensions of zoospores $\left(10^{4} \mathrm{ml}^{-1}\right)$. Two biological replicates were performed for each strain, and for each replicate the strain was inoculated onto ten leaflets taken from three independent plants. After being dipped into the zoospore fluid, leaflets were placed on water agar in plastic dishes, incubated in sealed bags at $15{ }^{\circ} \mathrm{C}$ for 1 day, and exposed to the temperature regimes described in Results. Leaflets infected with each sample were pooled and ground under liquid nitrogen, DNA was extracted from $100 \mathrm{mg}$ of the frozen powder using a $\mathrm{NaOH}$ extraction-Tris neutralization method, and qPCR was performed using primers O8-1 and O8-2, with three technical replicates (Judelson \& Tooley, 2000). This employed hot-start Taq polymerase in an iCycler (Bio-Rad), using SYBR Green and reactions of one cycle of $95{ }^{\circ} \mathrm{C}$ for $5 \mathrm{~min}$, followed by 35 cycles of $95{ }^{\circ} \mathrm{C}$ for $20 \mathrm{~s}, 53{ }^{\circ} \mathrm{C}$ for $20 \mathrm{~s}$ and $72{ }^{\circ} \mathrm{C}$ for $30 \mathrm{~s}$.

Sequence analysis. The $P$. infestans database at the Broad Institute was mined for genes of interest using keyword and BLASTP searches, including recursive searches to identify Hsp70-like proteins. Gene models were evaluated manually based on expressed sequence tag support and interspecific conservation, and corrected as needed. Phylogenetic analyses of the Hsp70 family were performed using alignments generated using MUSCLE (Edgar, 2004). Maximumlikelihood and distance-based trees were constructed using PhyML and BioNJ, respectively, using Seaview (Gouy et al., 2010). Mode support was calculated using SH-like aLRT values in PhyML or bootstrap values (500 replicates) in BioNJ.

RNA analysis. Non-sporulating hyphae grown in rye-sucrose broth were harvested 3-4 days after inoculation, frozen in liquid nitrogen, and ground to a powder. RNA was extracted using a commercial kit, treated with DNase, and assessed for quality by checking the $A_{260} / A_{280}$ ratio and by gel electrophoresis. Biological replicates were prepared no less than 10 days apart from each other.

For RT-PCR, RNA was reverse-transcribed using an oligo-dT primer. cDNA levels were normalized using primers for the gene encoding ribosomal protein S3a (Judelson et al., 2008). Typically, 10 ng cDNA was used per reaction. To detect PiERE1, end-point PCR was performed using primers $5^{\prime}$-TTCCCGAAAGCAGTGGCACCA-3' and $5^{\prime}$-CACGCTATTGCGCTCAGGACTA-3'. Gene expression was measured by semiquantitative or quantitative RT-PCR (qRT-PCR). The former was performed by running reactions for variable numbers of cycles as described in Results using Taq polymerase, followed by gel electrophoresis and staining with ethidium bromide. qRT-PCR employed hot-start Taq polymerase in an iCycler using SYBR Green. Reactions involved one cycle of $95{ }^{\circ} \mathrm{C}$ for $1 \mathrm{~min}$ (standard Taq) or $8 \mathrm{~min}$ (hot-start Taq), followed by cycles of $95{ }^{\circ} \mathrm{C}$ for $20 \mathrm{~s}$, $55{ }^{\circ} \mathrm{C}$ for $20 \mathrm{~s}$ and $72{ }^{\circ} \mathrm{C}$ for $30 \mathrm{~s}$. Two biological replicates for each treatment were analysed, with two technical replicates each. Relative expression was determined using the $2^{-\Delta \Delta C_{t}}$ method. For quality control, reactions lacking reverse transcriptase were performed and end-point products checked for the desired bands. Primers targeted 175-225 bp regions near the $3^{\prime}$ end of each gene.

\section{RESULTS}

\section{PiERE1 reduces the viability of aged cultures}

Our earlier publication reported that PiERE did not affect P. infestans (Judelson \& Fabritius, 2000), but a phenotype was revealed when our practice for maintaining cultures shifted from a 2- to a 6-month transfer cycle. Compared to PiERE1 $^{-}$strains, hyphae in the older PiERE1 ${ }^{+}$cultures lysed more often, which resulted in flattened patches within the culture. Whether this would influence the survival of $P$. infestans in nature is unclear, since hyphae are not believed to remain viable for long periods outside of plants. However, the observation led to a hypothesis that PiERE $1^{+}$strains are stressed, and spurred additional studies.

Our assessment of the effects of PiERE1 described above included analysing sexual progeny of strains $510\left(\right.$ PiERE1 $\left.^{+}\right)$ and $3117\left(\right.$ PiERE1 $^{-}$) as in our prior study (Judelson \& Fabritius, 2000). Even though PiERE1 copurifies with nuclei, its inheritance is usually but not always maternal and consequently only some $\mathrm{PiERE} 1^{+} \times \mathrm{PiERE}^{-}$offspring acquire the RNA element. This provides a way to study the effects of the element in genetically related strains. To try to assess the effects of PiERE1 in isogenic strains, we attempted to stably introduce it into $\mathrm{PiERE1}^{-}$strains by RNA transfection and transient DNA transformation using plasmids in which the element is fused to a constitutive promoter. Such attempts failed, however. The studies described next in this paper therefore continued to use the PiERE1 ${ }^{+}$and PiERE1 ${ }^{-}$progeny to assess the effects of the element.

\section{Strains containing PiERE1 are more thermotolerant}

Based on the premature lysis phenomenon described above, it seemed possible that additional deficiencies 
would be revealed in PiERE1 ${ }^{+}$strains under suboptimal growth conditions. Before testing this, the strains used in the earlier study were rechecked for PiERE1 by a RT-PCR assay that is more sensitive than the hybridization assay used previously. As shown in Fig. 1 for representative strains, this confirmed the status of the PiERE $1^{+}$parent (510), the PiERE1 ${ }^{-}$parent (3117), and several PiERE1 ${ }^{+}$ offspring (P1, P2, P3) and PiERE1 ${ }^{-}$offspring (N1, N2, N3, N4, N5). This also demonstrated that the RNA element had persisted in the strains through 8 years of subcultures. Also shown in Fig. 1 is the mitochondrial type as determined in our prior study (Judelson \& Fabritius, 2000). It should be noted that offspring N3 and N4 represent exceptions to the majority pattern of maternal inheritance of PiERE1 noted in our prior study.

The growth of PiERE1 ${ }^{+}$and PiERE1 ${ }^{-}$strains was then compared at supraoptimal temperatures, to check the hypothesis that strains containing PiERE1 would be less thermotolerant since they were already stressed. Previous workers have shown that $P$. infestans grows optimally near $20{ }^{\circ} \mathrm{C}$, so temperatures between $18{ }^{\circ} \mathrm{C}$ and $32{ }^{\circ} \mathrm{C}$ were tested (Mizubuti \& Fry, 1998; Sujkowski, 1987). Surprisingly, the PiERE1 ${ }^{+}$strains proved to be more thermotolerant than normal. As shown in Fig. 2(a), the optimal growth temperature for the PiERE1 ${ }^{+}$isolate 510 was $25{ }^{\circ} \mathrm{C}$ compared to $22{ }^{\circ} \mathrm{C}$ for four PiERE1 ${ }^{-}$isolates. Fig. 2(b) shows the same trend in the PiERE1 ${ }^{+}$(P1, P2, P3) and PiERE1 ${ }^{-}(\mathrm{N} 1, \mathrm{~N} 2, \mathrm{~N} 3, \mathrm{~N} 4, \mathrm{~N} 5)$ offspring of 510 and 3117. N3 and N4 contain the same mitochondrial genotype as 510 but do not exhibit greater thermotolerance, which shows that phenotype is not maternally inherited. Instead, the segregation of thermotolerance is associated strongly with the presence of PiERE1 $(P=0.03)$.

Evidence for greater thermotolerance of PiERE1 ${ }^{+}$strains was also revealed in studies of infected tomato leaflets. This involved dipping leaflets into zoospore suspensions,

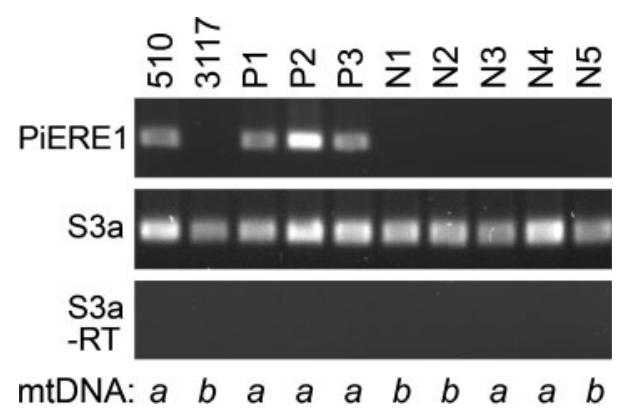

Fig. 1. Detection of PiERE1 in total RNA by RT-PCR. RNA was tested from strains 510 and 3117 , and representative progeny of those two strains that tested positive (P1, P2, P3) or negative (N1, N2, N3, N4, N5) for PiERE1. A a control, the RNA was also tested using primers for ribosomal protein $\mathrm{S} 3 \mathrm{a}$ with or without the reverse transcription step (S3a, S3a-RT). Also indicated is the mitochondrial genotype of each strain (Judelson \& Fabritius, 2000).

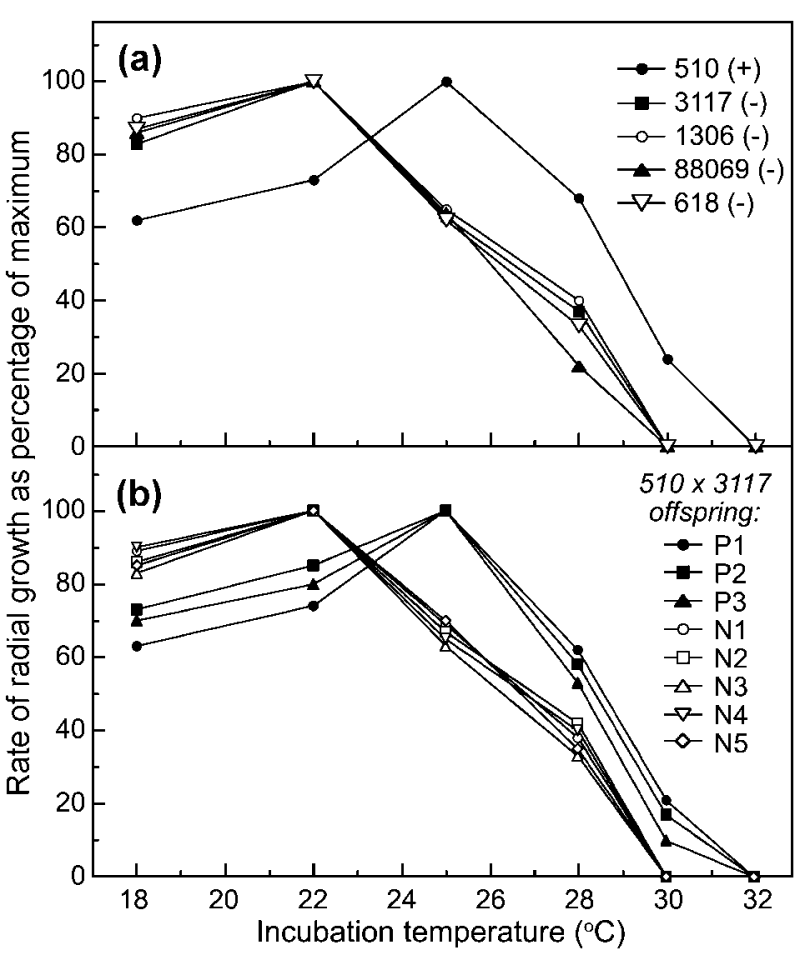

Fig. 2. Relationship between PiERE1 and optimum growth temperature. Strains were tested for growth between $18{ }^{\circ} \mathrm{C}$ and $32{ }^{\circ} \mathrm{C}$, and values are plotted as a percentage of the maximum. (a) Comparison of the PiERE $1^{+}$isolate 510 and five unrelated PiERE1- ${ }^{-}$strains; (b) analysis of the three PiERE1 ${ }^{+}$offspring of the $510 \times 3117$ cross (P1, P2, P3) and five PiERE1 ${ }^{-}$offspring (N1, N2, N3, N4, N5).

incubating the leaflets at $15{ }^{\circ} \mathrm{C}$ for $24 \mathrm{~h}$ to establish tissue-wide infections, exposing the leaflets to different temperature regimes, and measuring $P$. infestans DNA within the plant tissue by qRT-PCR using primers to a $P$. infestans-specific high-copy sequence (Judelson \& Tooley, 2000). When comparisons were made of leaflets held at $18{ }^{\circ} \mathrm{C}$ after the infection establishment period with those subjected to $12 \mathrm{~h} / 12 \mathrm{~h}$ cycles of $26{ }^{\circ} \mathrm{C}$ and $18{ }^{\circ} \mathrm{C}$, PiERE1 ${ }^{+}$ strains displayed enhanced abilities to grow or survive at the higher temperature. As shown in Fig. 3, each of two PiERE $^{+}{ }^{+}$strains tested (510 and offspring P2) showed slightly more growth when exposed to $26^{\circ} \mathrm{C}$ days than $18{ }^{\circ} \mathrm{C}$ days, although the difference is not significant at $P<0.05$. However, a decline in growth was observed at the higher temperature regime for PiERE1 ${ }^{-}$strains 3117 and offspring $\mathrm{N} 3$, and this difference is significant at $P=0.05$.

When analysing these in planta results, it is important to compare the relative growth of each strain between the two temperature regimes instead of comparing absolute growth rates between strains. This is because the pathogenicity of siblings can vary, as noted by workers studying strains that lack PiERE1 (Al-Kherb et al., 1995) as well as by our prior study of PiERE1 (Judelson \& Fabritius, 2000). As mentioned 


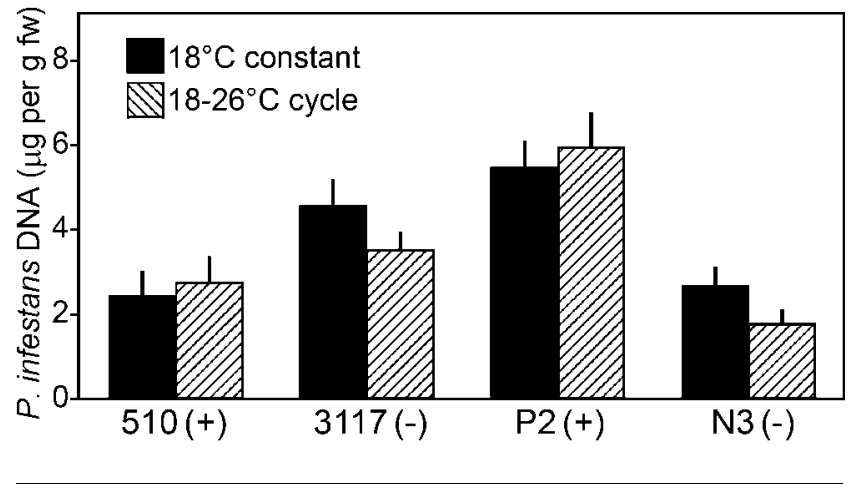

Fig. 3. Growth of $P$. infestans strains in tomato leaflets. Infections were established using zoospores from strains 510 and 3117, and their offspring $\mathrm{P} 2$ and $\mathrm{N} 3$, and then the leaflets were exposed to a constant temperature of $18{ }^{\circ} \mathrm{C}$ or cycled between $26{ }^{\circ} \mathrm{C}$ and $18^{\circ} \mathrm{C}$ for $12 \mathrm{~h}$ each. After $90 \mathrm{~h}$, DNA was extracted and quantified by PCR. Levels of DNA are expressed as $\mu \mathrm{g}$ per $\mathrm{g}$ tomato tissue (fresh weight), based on comparison to a standard curve of $P$. infestans genomic DNA. Two biological replicates were performed per strain, with three GPCR technical replicates per sample.

earlier, our prior study found no correlation between pathogenicity and the presence of the PiERE1 in a $16{ }^{\circ} \mathrm{C}$ growth chamber study.

It should be noted that the PiERE1 ${ }^{+}$strains showed poor growth in leaflets held at a constant temperature of $26^{\circ} \mathrm{C}$, as opposed to the $26{ }^{\circ} \mathrm{C}$ day $/ 18{ }^{\circ} \mathrm{C}$ night cycle (not shown). This conflicts with the in vitro data, where fairly good growth occurred up to $28{ }^{\circ} \mathrm{C}$. It is possible that the balance between host defences and $P$. infestans pathogenicity tipped towards the former when the higher temperatures were sustained. In nature, the temperature range in which epidemics proceed is also narrower than the range in which growth occurs on laboratory media (Harrison, 1992).

\section{PiERE1 increases secondary homothallism}

$P$. infestans is heterothallic with A1 and A2 mating types, with single strains usually not able to form oospores. However, it is reported that some strains of $P$. infestans and related species can produce oospores in single culture, especially when stressed by chemicals or physical damage (Groves \& Ristaino, 2000; Reeves \& Jackson, 1974). It was therefore hypothesized that the stresses induced by PiERE1 that lead to the early-lysis phenotype during long-term culture might also influence self-fertility.

Consistent with that hypothesis, PiERE1 ${ }^{+}$isolate 510 produced oospores in single culture (Fig. 4). Oospores were not noted in 2-week cultures, but were seen after 6 weeks. In contrast, oospores were never detected in cultures of the PiERE1 $^{-}$A1 strain 3117. Next, tests were made of four $\mathrm{PiERE}^{+}$and five PiERE1 ${ }^{-}$offspring of 510 and 3117 (P1$\mathrm{P} 4$ and N1-N5, respectively). This showed that the presence

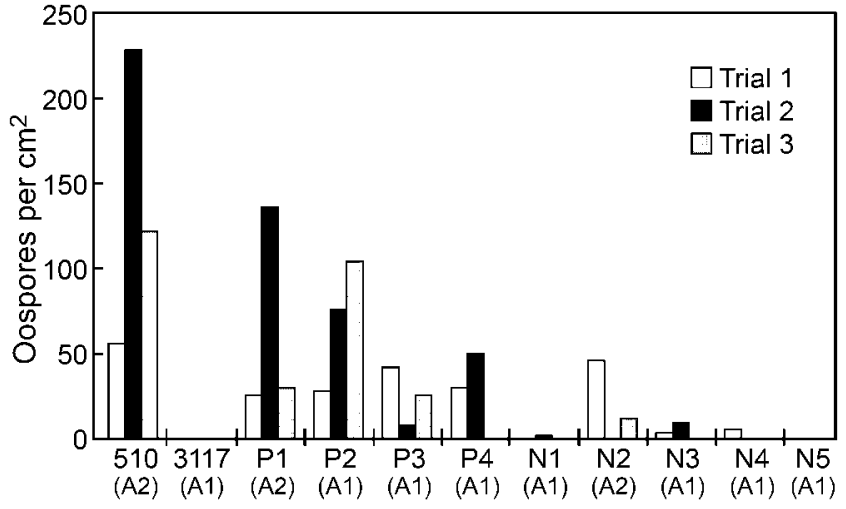

Fig. 4. Effect of PiERE1 on secondary homothallism. Oospore production was measured in single cultures of strains 510 and 3117, four PiERE1 ${ }^{+}$progeny (P1-P4), and five PiERE1- progeny (N1-N5). The mating types of the strains are indicated as A1 or A2. Data were collected from three independent trials conducted over a period of several months, except for N5, which was tested twice.

of PiERE1 correlated strongly with self-fertility $(P<0.01)$, with PiERE1 ${ }^{+}$offspring producing on average 7.3 times as many oospores as their PiERE1 ${ }^{-}$siblings. The number of oospores observed differed between replicates, but similar variation has also been reported in other studies of selffertility (Smart et al., 2000).

Prior researchers reported secondary homothallism in both A1 and A2 isolates of $P$. infestans (Groves \& Ristaino, 2000; Smart et al., 2000). In this study, the PiERE ${ }^{+}{ }^{+}$isolate was A2. However, secondary homothallism was observed in both A1 and A2 progeny. This is consistent with the determination of self-fertility in $P$. infestans (i.e. the breakdown of self-incompatibility) by a complex interaction between genetic loci, epigenetic factors and environment. It is also evident that the enhancement of self-fertility in our strains is unlinked to a maternal factor, since two of the PiERE1 ${ }^{-}$offspring had the same mitochondrial type as the PiERE1 ${ }^{+}$isolate 510.

\section{Effect of PiERE1 on stress biomarkers}

Measurements were made of the expression of six genes that act in conserved pathways for maintaining protein integrity during stress or to eliminate toxicants, and that are often induced as part of a general stress response (Venn et al., 2009). The product of gene Hsp70-2 belongs to a family of chaperone proteins first identified by their role in responding to heat shock but that also protect against other cellular insults (Feder \& Hofmann, 1999; Swindell et al., 2007). Also examined were two $A B C$ transporters that are known to be induced by a broad range of toxicants, $A B C B 14$ and ABCC6 (Judelson \& Senthil, 2006). Three genes involved in oxidative stress were also studied, including a catalase corresponding to gene model 
PITG_15248 in the genome database (http://www. broadinstitute.org), glutathione peroxidase PITG_02192, and superoxide dismutase PITG_07328.

Of the six stress biomarkers, only Hsp70-2 was expressed at higher levels in PiERE1 ${ }^{+}$strain 510 compared to PiERE1 ${ }^{-}$ strain 3117 based on semiquantitative RT-PCR (Fig. 5). The elevation of Hsp70-2 mRNA in the strain containing the RNA element is about fivefold. This experiment lacked biological replicates, but these will be presented later as part of qRT-PCR assays that confirm this result.

\section{Composition of the Hsp70 family of $\boldsymbol{P}$. infestans}

The Hsp70 family of $P$. infestans was characterized as a prerequisite to learning how it participates in the response to PiERE1. A search of the genome revealed 11 predicted members of the $H s p 70$ superfamily, which are listed in Table 1 as Hsp70-1 to 11. All contain standard hallmarks of the family, including $\mathrm{N}$-terminal ATPase and C-terminal peptide-binding domains that work together to protect proteins against aggregation or misfolding during stress. The count of 11 genes compares to 18 in Arabidopsis thaliana, 17 in humans and 8 in Saccharomyces cerevisiae (Boorstein et al., 1994; Brocchieri et al., 2008; Lin et al., 2001).

Hsp70 proteins in other taxa belong to either the DnaK or Hsp110/SSE subfamilies, and reside in several subcellular compartments. To classify the $P$. infestans proteins they were aligned against all Hsp70s from A. thaliana, human

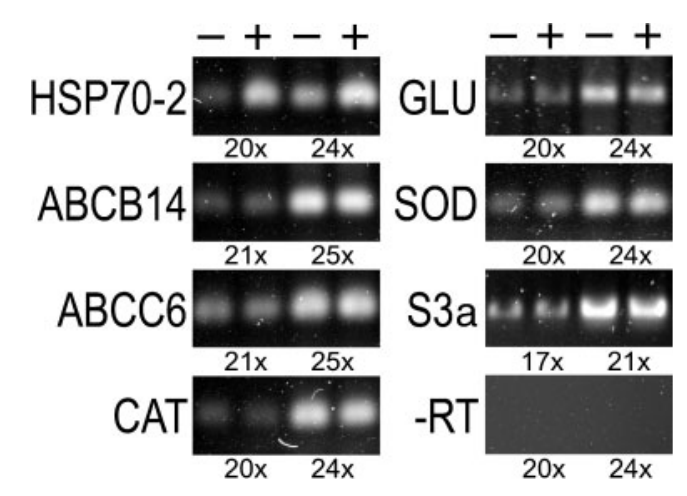

Fig. 5. Association between PiERE1 and expression of stress biomarkers. Semiquantitative RT-PCR was used to measure mRNA levels of genes encoding Hsp70-2, ABC transporters $A B C B 14$ and ABCC6, catalase (CAT), glutathione peroxidase (GLU) and superoxide dismutase (SOD) in $\mathrm{PiERE}^{-}$strain 3117 (-) and $\mathrm{PiERE}^{+}$strain $510(+)$. As a control, amplifications were performed using primers for the constitutively expressed gene encoding ribosomal protein $\mathrm{S} 3 \mathrm{a}$, with and without reverse transcriptase (S3a, -RT). Amplications were performed for varying numbers of cycles as indicated below each panel. ABCB14 and ABCC6 correspond to gene models PITG_05203 and PITG_06205 in the genome database; models for the other genes are given in the text. and S. cerevisiae, and subcellular localization was predicted using PSORT. The results are summarized in Table 1 and Fig. 6. The maximum-likelihood tree in Fig. 6 contains all $P$. infestans proteins and selected A. thaliana proteins, which are coded to indicate their subcellular location. Similar relationships were observed in trees constructed using all $A$. thaliana, human and $S$. cerevisiae proteins and in neighbour-joining trees (not shown).

Ten of the predicted Hsp70 proteins from P. infestans belong to the DnaK subfamily, and one to the Hsp110/SSE subfamily. One DnaK protein is predicted to reside in mitochondria, two in endoplasmic reticulum (ER), and six in the cytoplasm. Genes for four cytoplasmic DnaK proteins (Hsp70-2, 3, 4, 5) reside within $75 \mathrm{~kb}$ of each other, which suggests that they evolved from a common ancestor. Their proteins also contain a C-terminal EEVD that is found in cytoplasmic Hsp70 proteins in other taxa (Boorstein et al., 1994). One DnaK protein, Hsp70-7, has a C-terminal HDEL domain that marks proteins for retention in the ER (Vitale et al., 1993). Hsp70-8 is also predicted to reside in the ER since it has a C-terminal transmembrane domain.

The single Hsp110/SSE protein, Hsp70-11, is predicted to reside in the ER since it contains a C-terminal KDEL retention signal (Vitale et al., 1993). By comparison, many eukaryotes express both cytoplasmic and ER-based Hsp110/SSE proteins. Like other members of this subfamily, Hsp70-11 contains a longer linker between the ATPase and peptide-binding domains compared to DnaK proteins.

$P$. infestans protein Hsp70-10 clustered with the chloroplast AtHsp70-8 protein from A. thaliana. Bootstrap analysis indicated that the grouping was not strong, but this is of interest since oomycete evolution involved a secondary endosymbiosis event with a photosynthetic red algae (Robertson \& Tartar, 2006). However, Hsp70-10 may be a pseudogene since we could not obtain evidence for its expression by RT-PCR.

Other pseudogenes were also detected, as their gene models contain stop codons within Hsp70-like sequences (PITG_05721, PITG_09693, PITG_11422, PITG_15111, PITG_15370, PITG_18517, and PITG_18939). Most other large eukaryotic genomes also contain Hsp70 pseudogenes (Brocchieri et al., 2008; Lin et al., 2001).

\section{Four Hsp70 genes are upregulated by PiERE1}

The expression of the Hsp70 genes in PiERE1 ${ }^{+}$and PiERE1 ${ }^{-}$strains was measured by qRT-PCR. This entailed analysing strains 510 and 3117 , three of their PiERE1 ${ }^{+}$ offspring, and four PiERE1 ${ }^{-}$offspring. Two biological replicates of each strain were examined and two technical replicates were performed per RNA sample. Nine genes representing the diversity within the $H s p 70$ family were studied, although signals were not detected for Hsp70-10. Of the eight genes for which mRNA could be detected, higher mRNA levels were observed in PiERE1 ${ }^{+}$strains for 
Table 1. Hsp70 genes in the P. infestans genome

\begin{tabular}{|c|c|c|c|c|c|}
\hline Subfamily & Gene & Database accession no. & Mol. mass (kDa) & Evidence of expression ${ }^{*}$ & Predicted localization $\dagger$ \\
\hline \multirow[t]{8}{*}{ DnaK } & Hsp70-1 & PITG_03546 & 61.1 & EST, RT & Cytoplasm \\
\hline & Hsp70-2 & PITG_11244 & 72.2 & EST, RT & Cytoplasm \\
\hline & Hsp70-4 & PITG_11249 & 71.7 & EST, RT & Cytoplasm \\
\hline & Hsp70-5 & PITG_11252 & 71.8 & EST, RT & Cytoplasm \\
\hline & Hsp70-6 & PITG_11913 & 86.6 & EST, RT & Cytoplasm \\
\hline & $H s p 70-8$ & PITG_16528 & 61.1 & EST, RT & ER \\
\hline & Hsp70-9 & PITG_15786 & 68.1 & EST, RT & Mitochondrion \\
\hline & Hsp70-10 & PITG_21580 & 75.5 & - & Cytoplasm \\
\hline Hsp110/SSE & Hsp70-11 & PITG_15771 & 98.1 & EST, RT & ER \\
\hline
\end{tabular}

${ }^{\star}$ Based on presence of expressed sequence tags (EST) or signals in RT-PCR (RT).

$\dagger$ Predicted using PSORT version 6.4 (Nakai \& Horton, 1999).

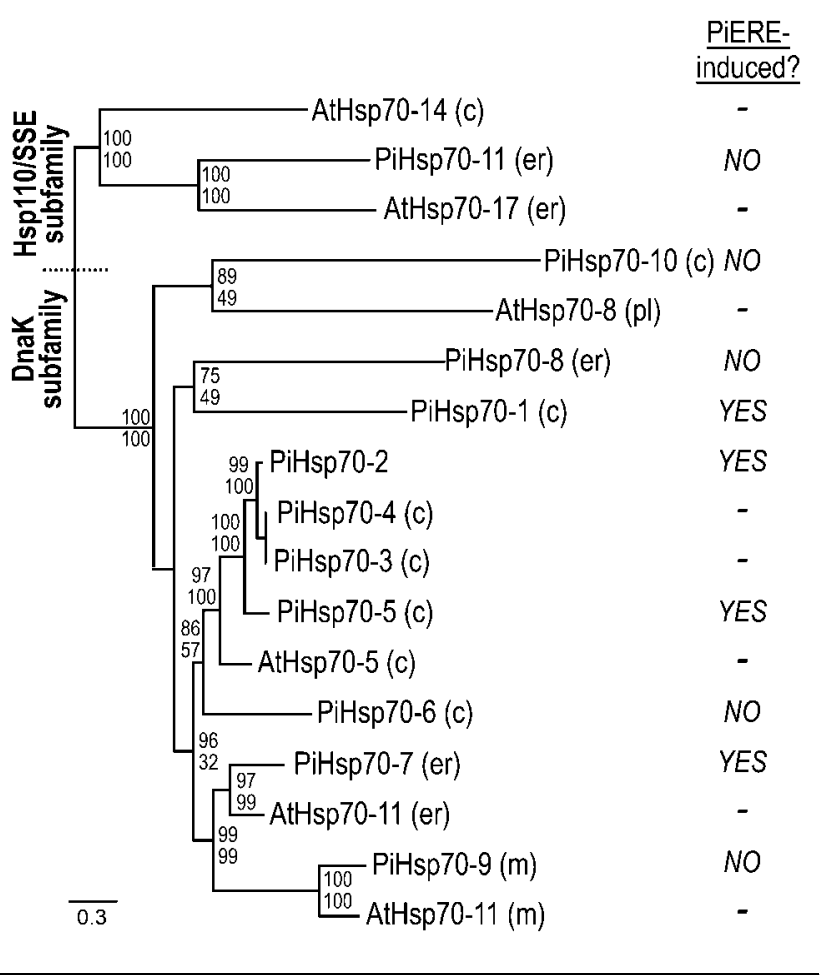

Fig. 6. Phylogenetic analysis of Hsp70 proteins and definition of the DnaK and Hsp110/SSE subfamilies. P. infestans and selected $A$. thaliana proteins were aligned using MUSCLE, and a maximumlikelihood tree was made using PhyML. Sequences are labelled with $\mathrm{Pi}$ and At prefixes, respectively, the latter using the nomenclature of Lin et al. (2001). Following each name is a code indicating whether the proteins are predicted to reside in the cytoplasm (c), endoplasmic reticulum (er), mitochondia (m), or plastid (pl). Shown at nodes are aLRT support values from PhyML (upper number) or bootstrap values (lower number, percentage occurrence) from a neighbour-joining tree made using BioNJ, which had a similar topology. The column on the right indicates which $P$. infestans genes have elevated expression in PiEREcontaining strains based on the data in Fig. 7 .
Hsp70-1, 2, 5 and 7, which all belong to the DnaK subfamily (Fig. 7). The differences in mRNA levels between the PiERE1 ${ }^{+}$and PiERE1 ${ }^{-}$groups ranged from 1.5- to 4.5fold increases for $H s p 70-5$ and $H s p 70-7$, respectively, and were statistically significant $(P<0.01)$.

\section{Expression of genes with sequence matches to PiERE1}

Some symptoms of viroids may be due to their destabilization of plant mRNAs through silencing pathways (Gómez et al., 2009). To test if this relates to the effect of PiERE1 on $P$. infestans, the genome database was searched for transcripts similar to PiERE1. Although some studies of siRNAs indicate that as few as 11 contiguous identical nucleotides can trigger silencing, we focused on the 10 genes having more than 16 nucleotides of identity (Jackson et al., 2003). These included eight genes with 16 or more contiguous bases identical to PiERE1, and two with 17 identical bases allowing for 1 internal mismatch. No differences were observed in their mRNA levels between PiERE ${ }^{+}$and PiERE1siRNA strains. Of course, this may not accurately represent effects of PiERE1 at the protein level if a miRNA-like translational blockage is involved.

\section{DISCUSSION}

The key finding from this study is that an RNA symbiont that was previously believed not to influence the biology of $P$. infestans does alter its growth. The effects were subtle and revealed only under certain conditions, but may be ecologically significant. The spread of late-blight epidemics in many potato- and tomato-growing regions arrests when seasonal temperatures rise above that tolerated by $P$. infestans (Harrison, 1992). The ability of PiERE $1^{+}$strains to grow over an expanded range of temperatures therefore may compensate for the deleterious effects of diverting cellular resources to support PiERE1 replication. A similar 


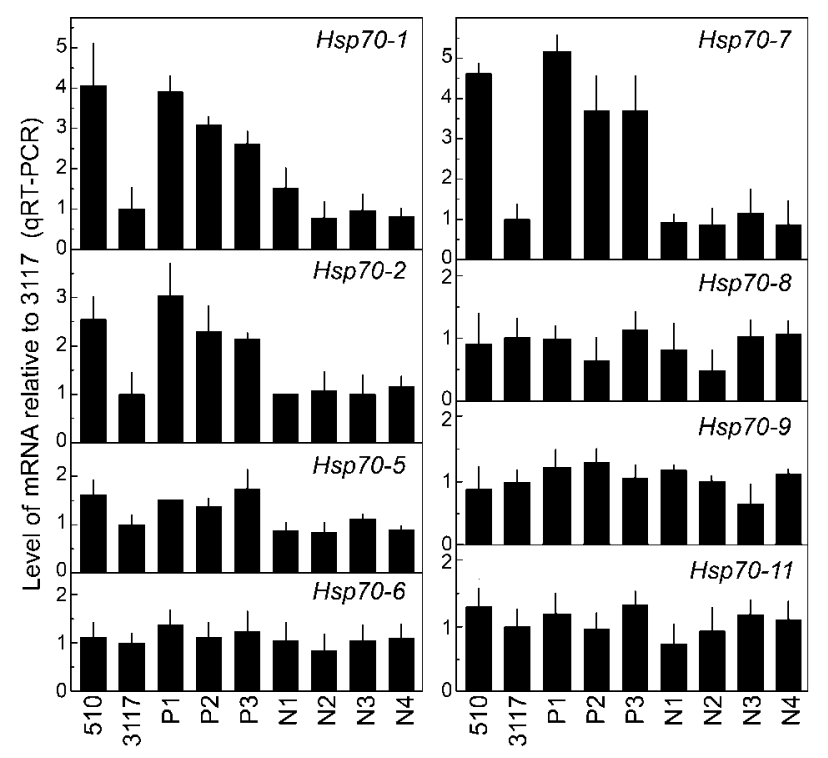

Fig. 7. Relationship between PiERE1 and expression of Hsp70 genes. qRT-PCR was used to measure mRNA levels of the indicated genes in hyphae of strains 510 and 3117, three PiERE1 ${ }^{+}$(P1, P2, P3), and four PiERE1 ${ }^{-}$(N1, N2, N3, N4) progeny. Values are normalized to ribosomal protein $\mathrm{S} 3 \mathrm{a}$ and adjusted such that the level of mRNA in strain 3117 equals 1.0. Two biological replicates were tested per sample, with two technical replicates each. Expression levels of the PiERE $1^{+}$and PiERE1- groups were significantly different for Hsp70-1, Hsp702, Hsp70-5 and Hsp70-7, with $P<0.01$ for each of those four genes in two-tailed, two-sample equal variance $t$-tests. Expression of the remaining genes was not significantly different between the PiERE $1^{+}$and PiERE1 ${ }^{-}$groups, as each $P$-value was $>0.25$.

benefit results from the increased formation of oospores, which may persist between growing seasons and provide inoculum for new disease outbreaks (Grunwald \& Flier, 2005). Therefore, our new data define the interaction between PiERE1 and P. infestans as a mutualism.

The prevalence of mutualisms between RNA or DNA parasites and their hosts remains to be determined, as this has been little studied due to natural bias of scientists towards examining pathogenic interactions. While it is recognized that benign symbioses involving virus-like agents are common in animals, fungi, oomycetes and plants (Pearson et al., 2009; Roossinck, 2008), in most cases rigorous tests for beneficial or detrimental effects have not been performed. In Aspergillus, however, one virus defined previously as cryptic was found to have a small detrimental impact on its host (van Diepeningen et al., 2006). There is also an example of a mutualistic interaction involving a dsRNA virus and the plant-pathogenic fungus Nectria radicicola, where eliminating the virus reduced virulence (Ahn \& Lee, 2001). Of course, if one expands the definition of a parasite to include DNA plasmids, there are many examples of mutualisms within prokaryotes.
Explaining the effects of PiERE1 on $P$. infestans is challenging since its mode of replication is unknown. We have so far been unsuccessful in developing infectious DNA clones, or transferring PiERE1 by RNA-based transformation, which could be used to address such questions. However, it is likely that replication involves an RNAdirected RNA polymerase as with viroids (Flores et al., 2005), and genes encoding several of these enzymes can be identified from the P. infestans genome (Ah-Fong et al., 2008). Although we have not been able to detect other extrachromosomal RNAs in the original PiERE1 ${ }^{+}$isolate, 510, we can not exclude the possibility that PiERE1 is a satellite of an undetected virus which provides the enzyme for replication. This could also explain our inability to develop infectious clones. Like most viruses and their satellites (Ahlquist, 2006), PiERE1 may replicate in a specific cellular organelle, and this may interfere with normal host activities. PiERE1 copurified with nuclei in detergent-treated cells, but this does exclude the possibility of it associating with other particulate structures or organelles.

The disruption of several types of cellular processes could explain why Hsp70 genes are upregulated in PiERE $1^{+} P$. infestans. Hsp70 was detected originally as a protein that is strongly induced during heat stress, and which uses its chaperone activity to bind proteins that unfold at elevated temperatures, prevent them from aggregating, and help them to refold (Feder \& Hofmann, 1999). However, it is now recognized that many Hsp70 genes are also induced by diverse stimuli that do not induce protein denaturation or aggregation, and that some are not heat-inducible or play housekeeping functions (Brocchieri et al., 2008; Daugaard et al., 2007; Feder \& Hofmann, 1999). For example, in A. thaliana subsets of both cytoplasmic and ER-resident DnaK and Hsp110/SSE subfamily members are induced by heat, cold, oxidative stress, DNA damage or osmotic shock (Swindell et al., 2007). Similarly, in animal cells some Hsp70 proteins are involved in responses to starvation, osmotic stress, growth hormones, microtubule-disturbing drugs and DNA damage in addition to temperature stress (Daugaard et al., 2007). As appears to be the case in $P$. infestans, Hsp70 genes in animals and plants are not induced coordinately, with subsets reacting to one stress or another. It is also notable that Hsp70 genes are often induced during virus infections (Jindal \& Young, 1992; Whitham et al., 2006).

The purpose of this study was to examine the biological effects of PiERE1 on $P$. infestans, not to analyse the functions of the $H s p 70$ gene family in detail. Nevertheless, it is logical to assume that increased Hsp70 production is responsible for the greater thermotolerance of strains containing PiERE1. Overexpression of Hsp70 transgenes is known to increase thermotolerance in filamentous fungi, plants and animals (Krebs \& Feder, 1998; MonteroBarrientos et al., 2008; Sung \& Guy, 2003). Those studies also reported that overexpression caused developmental defects in Arabidopsis and Drosophila, although not in the 
fungal system. It is therefore interesting to speculate whether the secondary homothallism of the PiERE1 ${ }^{+}$ strains results from the same stresses that induce Hsp70, or is a secondary outcome of Hsp70 overexpression.

Secondary homothallism appears to result from a breakdown in the regulatory apparatus that controls mating, and is described for several species of Phytophthora (Groves \& Ristaino, 2000; Reeves \& Jackson, 1974). Oomycetes are classified traditionally as either homothallic (self-fertile) or heterothallic, where two strains of opposite mating types must interact to enable oosporogenesis. In Phytopthora, mating type is regulated by hormones and determined by a single locus at which A1 is heterozygous $(A / a)$ and A2 homozygous (a/a) (Judelson, 1996; Ko, 1988). However, there is no self-incompatibility barrier, so a single strain of a heterothallic species can form selfed oospores once the mating pathway is induced. It is conceivable that a cellular stress could destabilize a regulatory protein and thus trigger selfing. This could be a consequence of Hsp70 overexpression, since one of its functions is to target proteins for ubiquitination and proteolysis (Petrucelli et al., 2004). While such a direct effect of Hsp70 on the sexual machinery is speculative, it is reasonable to suggest that Hsp70 genes can be used as biomarkers for stresses associated with cryptic RNA or DNA parasites.

\section{ACKNOWLEDGEMENTS}

This work was supported by an award from the National Science Foundation of the United States to H.S. J.

\section{REFERENCES}

Ah-Fong, A. M., Bormann-Chung, C. A. \& Judelson, H. S. (2008), Optimization of transgene-mediated silencing in Phytophthora infestans and its association with small-interfering RNAs. Fungal Genet Biol 45, 1197-1205.

Ahlquist, P. (2006). Parallels among positive-strand RNA viruses, reverse-transcribing viruses and double-stranded RNA viruses. Nat Rev Microbiol 4, 371-382.

Ahn, I. P. \& Lee, Y. H. (2001). A viral double-stranded RNA up regulates the fungal virulence of Nectria radicicola. Mol Plant Microbe Interact 14, 496-507.

Al-Kherb, S. M., Fininsa, C., Shattock, R. C. \& Shaw, D. S. (1995). The inheritance of virulence of Phytophthora infestans to potato. Plant Pathol 44, 552-562.

Boorstein, W. R., Ziegelhoffer, T. \& Craig, E. A. (1994). Molecular evolution of the HSP70 multigene family. J Mol Evol 38, 1-17.

Brocchieri, L., Conway de Macario, E. \& Macario, A. J. (2008). hsp70 genes in the human genome: conservation and differentiation patterns predict a wide array of overlapping and specialized functions. BMC Evol Biol 8, 19.

Cai, G., Myers, K., Hillman, B. I. \& Fry, W. E. (2009). A novel virus of the late blight pathogen, Phytophthora infestans, with two RNA segments and a supergroup 1 RNA-dependent RNA polymerase. Virology 392, 52-61.

Caten, C. E. \& Jinks, J. L. (1968). Spontaneous variability in isolates of Phytophthora infestans. I. Cultural variation. Can J Bot 46, 329-348.
Daugaard, M., Rohde, M. \& Jaattela, M. (2007). The heat shock protein 70 family: highly homologous proteins with overlapping and distinct functions. FEBS Lett 581, 3702-3710.

Deterding, K., Tegtmeyer, B., Cornberg, M., Hadem, J., Potthoff, A., Boker, K. H., Tillmann, H. L., Manns, M. P. \& Wedemeyer, H. (2006). Hepatitis A virus infection suppresses hepatitis $C$ virus replication and may lead to clearance of HCV. J Hepatol 45, 770-778.

Edgar, R. C. (2004). MUSCLE: a multiple sequence alignment method with reduced time and space complexity. BMC Bioinformatics 5, 113 .

Feder, M. E. \& Hofmann, G. E. (1999). Heat-shock proteins, molecular chaperones, and the stress response: evolutionary and ecological physiology. Annu Rev Physiol 61, 243-282.

Flores, R., Hernandez, C., Martinez de Alba, A. E., Daros, J. A. \& Di Serio, F. (2005). Viroids and viroid-host interactions. Annu Rev Phytopathol 43, 117-139.

Gómez, G., Martínez, G. \& Pallás, V. (2009). Interplay between viroidinduced pathogenesis and RNA silencing pathways. Trends Plant Sci 14, 264-269.

Gouy, M., Guindon, S. \& Gascuel, O. (2010). SeaView version 4: a multiplatform graphical user interface for sequence alignment and phylogenetic tree building. Mol Biol Evol 27, 221-224.

Groves, C. T. \& Ristaino, J. B. (2000). Commercial fungicide formulations induce in vitro oospore formation and phenotypic change in mating type in Phytophthora infestans. Phytopathology 90, 1201-1208.

Grunwald, N. J. \& Flier, W. G. (2005). The biology of Phytophthora infestans at its center of origin. Annu Rev Phytopathol 43, 171-190.

Hacker, C. V., Brasier, C. M. \& Buck, K. W. (2005). A double-stranded RNA from a Phytophthora species is related to the plant endornaviruses and contains a putative UDP glycosyltransferase gene. J Gen Virol 86, 1561-1570.

Harrison, J. G. (1992). Effects of the aerial environment on late blight of potato foliage, a review. Plant Pathol 41, 384-416.

Jackson, A. L., Bartz, S. R., Schelter, J., Kobayashi, S. V., Burchard, J., Mao, M., Li, B., Cavet, G. \& Linsley, P. S. (2003). Expression profiling reveals off-target gene regulation by RNAi. Nat Biotechnol 21, 635637.

Jindal, S. \& Young, R. A. (1992). Vaccinia virus infection induces a stress response that leads to association of Hsp70 with viral proteins. J Virol 66, 5357-5362.

Judelson, H. S. (1996). Genetic and physical variability at the mating type locus of the oomycete, Phytophthora infestans. Genetics 144, 1005-1013.

Judelson, H. S. \& Fabritius, A. L. (2000). A linear RNA replicon from the oomycete Phytophthora infestans. Mol Gen Genet 263, 395-403.

Judelson, H. S. \& Senthil, G. S. (2006). Investigating the role of ABC transporters in multifungicide insensitivity in Phytophthora infestans. Mol Plant Pathol 7, 17-29.

Judelson, H. S. \& Tooley, P. W. (2000). Enhanced polymerase chain reaction methods for detecting and quantifying Phytophthora infestans in plants. Phytopathology 90, 1112-1119.

Judelson, H. S., Ah-Fong, A. M., Aux, G., Avrova, A. O., Bruce, C., Cakir, C., da Cunha, L., Grenville-Briggs, L., Latijnhouwers, M. \& other authors (2008). Gene expression profiling during asexual development of the late blight pathogen Phytophthora infestans reveals a highly dynamic transcriptome. Mol Plant Microbe Interact 21, 433447.

Klassen, G. R., Kim, W. K., Barr, D. J. S. \& Desaulniers, N. L. (1991). Presence of double-stranded RNA in isolates of Pythium irregulare. Mycologia 83, 657-661. 
Ko, W. H. (1988). Hormonal heterothallism and homothallism in Phytophthora. Annu Rev Phytopathol 26, 57-73.

Krebs, R. A. \& Feder, M. E. (1998). Hsp70 and larval thermotolerance in Drosophila melanogaster: how much is enough and when is more too much? J Insect Physiol 44, 1091-1101.

Lin, B. L., Wang, J. S., Liu, H. C., Chen, R. W., Meyer, Y., Barakat, A. \& Delseny, M. (2001). Genomic analysis of the Hsp70 superfamily in Arabidopsis thaliana. Cell Stress Chaperones 6, 201-208.

Márquez, L. M., Redman, R. S., Rodriguez, R. J. \& Roossinck, M. J. (2007). A virus in a fungus in a plant: three-way symbiosis required for thermal tolerance. Science 315, 513-515.

Mizubuti, E. S. G. \& Fry, W. E. (1998). Temperature effects on development stages of isolates from three clonal lineages of Phytophthora infestans. Phytopathology 88, 837-843.

Montero-Barrientos, M., Hermosa, R., Nicolas, C., Cardoza, R. E., Gutierrez, S. \& Monte, E. (2008). Overexpression of a Trichoderma HSP70 gene increases fungal resistance to heat and other abiotic stresses. Fungal Genet Biol 45, 1506-1513.

Moran, N. A., Degnan, P. H., Santos, S. R., Dunbar, H. E. \& Ochman, H. (2005). The players in a mutualistic symbiosis: insects, bacteria, viruses, and virulence genes. Proc Natl Acad Sci U S A 102, 1691916926.

Nakai, K. \& Horton, P. (1999). PSORT: a program for detecting the sorting signals of proteins and predicting their subcellular localization. Trends Biochem Sci 24, 34-35.

Newhouse, J. R., Tooley, P. W., Smith, O. P. \& Fishel, R. A. (1992). Characterization of double-stranded RNA in isolates of Phytophthora infestans from Mexico, the Netherlands, and Peru. Phytopathology 82, 164-169.

Oppenheim, A. B., Kobiler, O., Stavans, J., Court, D. L. \& Adhya, S. (2005). Switches in bacteriophage lambda development. Annu Rev Genet 39, 409-429.

Pearson, M. N., Beever, R. E., Boine, B. \& Arthur, K. (2009). Mycoviruses of filamentous fungi and their relevance to plant pathology. Mol Plant Pathol 10, 115-128.

Petrucelli, L., Dickson, D., Kehoe, K., Taylor, J., Snyder, H., Grover, A., De Lucia, M., McGowan, E., Lewis, J. \& other authors (2004). CHIP and $\mathrm{Hsp} 70$ regulate tau ubiquitination, degradation and aggregation. Hum Mol Genet 13, 703-714.

Reeves, R. J. \& Jackson, R. M. (1974). Stimulation of sexual reproduction in Phytophthora cinnamomi by damage. J Gen Microbiol 84, 303-310.

Robertson, D. L. \& Tartar, A. (2006). Evolution of glutamine synthetase in heterokonts: evidence for endosymbiotic gene transfer and the early evolution of photosynthesis. Mol Biol Evol 23, 10481055.

Roossinck, M. J. (2008). Symbiosis, mutualism and symbiogenesis. In Plant Virus Evolution, pp. 157-164. Edited by M. J. Roossinck. Heidelberg: Springer Verlag.

Schmitt, M. J. \& Breinig, F. (2006). Yeast viral killer toxins: lethality and self-protection. Nat Rev Microbiol 4, 212-221.

Smart, C. D., Mayton, H., Mizubuti, E. S. G., Willmann, M. R. \& Fry, W. E. (2000). Environmental and genetic factors influencing self-fertility in Phytophthora infestans. Phytopathology 90, 987-994.

Stasiak, K., Renault, S., Federici, B. A. \& Bigot, Y. (2005). Characteristics of pathogenic and mutualistic relationships of ascoviruses in field populations of parasitoid wasps. J Insect Physiol 51, 103-115.

Sujkowski, L. S. (1987). The Influence of temperature on Phytophthora infestans Mont. de Bary. J Phytopathol 120, 271-275.

Sung, D. Y. \& Guy, C. L. (2003). Physiological and molecular assessment of altered expression of Hsc70-1 in Arabidopsis. Evidence for pleiotropic consequences. Plant Physiol 132, 979-987.

Swindell, W. R., Huebner, M. \& Weber, A. P. (2007). Transcriptional profiling of Arabidopsis heat shock proteins and transcription factors reveals extensive overlap between heat and non-heat stress response pathways. BMC Genomics 8, 125.

Van Alfen, N. K., Jaynes, R. A., Anagnostakis, S. L. \& Day, P. R. (1975). Chestnut blight: biological control by transmissible hypovirulence in Endothia parasitica. Science 189, 890-891.

van Diepeningen, A. D., Debets, A. J. \& Hoekstra, R. F. (2006). Dynamics of dsRNA mycoviruses in black Aspergillus populations. Fungal Genet Biol 43, 446-452.

van Nunen, A. B., Pontesilli, O., Uytdehaag, F., Osterhaus, A. D. \& de Man, R. A. (2001). Suppression of hepatitis B virus replication mediated by hepatitis A-induced cytokine production. Liver 21, 4549.

Venn, A. A., Quinn, J., Jones, R. \& Bodnar, A. (2009). P-glycoprotein (multi-xenobiotic resistance) and heat shock protein gene expression in the reef coral Montastraea franksi in response to environmental toxicants. Aquat Toxicol 93, 188-195.

Vitale, A., Ceriotti, A. \& Denecke, J. (1993). The role of the endoplasmic reticulum in protein synthesis, modification and intracellular transport. J Exp Bot 44, 1417-1444.

Whitham, S. A., Yang, C. \& Goodin, M. M. (2006). Global impact: elucidating plant responses to viral infection. Mol Plant Microbe Interact 19, 1207-1215.

Edited by: N. P. Keller 